DOI :

\begin{tabular}{l|lll}
\hline History Article & Received: Maret 2020 & Approved: Maret 2020 & Published: Maret 2020 \\
\hline
\end{tabular}

\title{
PENGARUH METODE PEMBELAJARAN MIND MAPPING DAN MOTIVASI BELAJAR TERHADAP KETERAMPILAN BERPIKIR KREATIF PESERTA DIDIK PADA MATERI INVERTEBRATA
}

\author{
${ }^{1}$ W.F. Novitasari, ${ }^{2}$ Hening Widowati, ${ }^{3}$ Achyani
}

\author{
${ }^{123}$ Program Pascasarjana Pendidikan Biologi, Universitas Muhammadiyah Metro

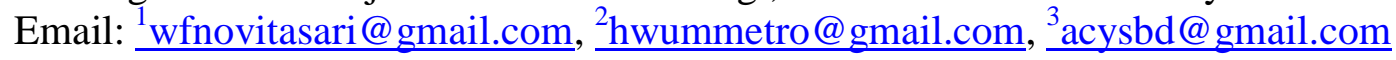

\begin{abstract}
Abstrak : Penelitian bertujuan mengetahui: (1) Pengaruh metode pembelajaran mindmapping terhadap keterampilan berpikir kreatif peserta didik pada materi Invertebrata (2) Pengaruh motivasi belajar peserta didik terhadap keterampilan berpikir kreatif peserta didik pada materi Invertebrata (3) Interaksi antara metode pembelajaran mind mapping dan motivasi belajar yang berbeda terhadap kemampuan berpikir kreatif peserta didik pada materi Invertebrata. Rancangan penelitian yang digunakan dalam penelitian ini adalah rancangan penelitian eksperimen semu atau quasi eksperiment. Desain yang digunakan adalah Pre Test-Post Test Nonequivalent Control Group Design.. Hasil analisis menunjukkan: (1) Terdapat pengaruh yang signifikan terkait metode pembelajaran mind mapping terhadap keterampilan berpikir kreatif peserta didik pada materi Invertebrata. (2) Tidak terdapat pengaruh yang signifikan terkait motivasi belajar peserta didik terhadap keterampilan berpikir kreatif peserta didik pada materi Invertebrata. (3) Tidak terdapat interaksi antara metode pembelajaran mind mapping dan motivasi belajar yang berbeda terhadap kemampuan berpikir kreatif peserta didik pada materi Invertebrata.
\end{abstract}

Kata Kunci: pembelajaran mind mapping, motivasi belajar, keterampilan berpikir kreatif

Abstract : The aim of the research were to know: (1) the effect of mind mapping learning method toward student's creative thingking skill in invertebrates, (2) the effect of student's learning motivation to ward student's creative thingking skill ininvertebrata, (3) interaction between mind mapping learning method and different learning motivation to ward student's creative thingking skill in invertebrata. The research design used in this experiment was experimental research design or quasi experiment. The design that used was Pre-Test-Post Test Non equivalent Control Group Design. The analysis result showed that (1) there was a significant effect related to mind mapping learning method toward student's creative thingking skill in invertebrates, (2) there was no significant effectof student's learning motivation toward student's creative thingking skill in invertebrates, (2) there was no interaction between mind mapping learning method and different learning motivation toward student's creative thingking skill in invertebrates.

Keywords: mind mapping learning method, learning method, creative thinking skill

\section{How to Cite}

Novitasari, W.F. Hening Widowati, \& Achyani. 2020. Pengaruh Metode Pembelajaran Mind Mapping Dan Motivasi Belajar Terhadap Keterampilan Berpikir Kreatif Peserta Didik Pada Materi Invertebrata . Biolova 1(2). 142-149. 
Keterampilan

berpikir merupakan salah satu aspek dari tujuan pembelajaran biologi. Mata pelajaran biologi merupakan mata pelajaran sangat penting dan wajib dipelajari dalam kurikulum tahun 2013. Pada kurikulum tahun 2013, peserta didik dituntut mampu menjadi pribadi yang lebih komunikatif, mampu berkolaborasi dengan kelompok, berpikir kritis dalam memecahkan masalah serta lebih kreatif. Materi yang diajarkan dalam pembelajaran biologi bukan hanya berupa fakta-fakta, konsep maupun prinsip saja, namun juga terdapat adanya proses penemuan. Pembelajaran biologi memerlukan suatu strategi yang tepat agar keterampilan berpikir peserta didik dapat terakses dengan baik karena pembelajaran biologi merupakan serangkaian proses yang tidak hanya digunakan sebagai wahana untuk meningkatkan pengetahuan saja, akan tetapi juga meningkatkan keterampilan dan juga kreativitas peserta didik. Sawyer (2003: 20) menyatakan bahwa kreativitas itu sulit untuk didefinisikan, namun Sani (2014: 13) memaparkan bahwa kreativitas terkait dengan tiga komponen utama yaitu berpikir kreatif, keahlian (pengetahuan teknis, prosedural dan intelektual), dan motivasi.

Hasil observasi menunjukkan bahwa pembelajaran biologi di Kelas XI MIPA SMA Negeri 6 Metro sudah menunjukkan adanya aktivitas belajar peserta didik, namun belum mendekati pada kualitas dan produk belajar. Hal tersebut dibuktikan pada saat proses diskusi dan presentasi hanya sebagian peserta didik yang aktif berpendapat dan menyanggah pendapat temannya, sementara sebagian besar peserta didik lainnya cenderung masih pasif.
Kesenjangan yang nampak antara kondisi yang diharapkan dengan kenyataan di lapangan membuktikan bahwa seharusnya pembelajaran, dalam hal ini khususnya biologi, harus berbasis kompetensi sekaligus berbasis karakter (competency and character based curriculum), yang dapat membekali peserta didik dengan berbagai sikap dan kemampuan yang sesuai dengan tuntutan perkembangan zaman dan tuntutan teknologi sehingga diharapkan dapat menghasilkan peserta didik yang produktif, kreatif, inovatif, dan efektif.

Mind mapping sebagai salah satu bentuk metode pembelajaran digunakan untuk melatih kemampuan menyajikan isi (content) materi pelajaran dengan pemetaan pikiran sangat tepat untuk diaplikasikan. Mind mapping dikembangkan oleh Buzan (2002) sejak akhir tahun 1960-an sebagai cara untuk mendorong peserta didik mencatat hanya dengan menggunakan kata kunci dan Gambar serta merupakan cara paling efektif dan efisien dalam menyimpan, memasukkan, dan mengeluarkan pengetahuan dari atau ke otak. Akbar (2017: 76) menambahkan bahwa menggunakan mind mapping mampu membuat peserta didik mengingat materi lebih lama. Berdasarkan rumusan masalah, maka dapat dikemukakan tujuan dari penelitian ini adalah 1) Mengetahui pengaruh metode pembelajaran mind mapping terhadap keterampilan berpikir kreatif peserta didik pada materi Invertebrata; 2) Mengetahui pengaruh motivasi belajar peserta didik terhadap keterampilan berpikir kreatif peserta didik pada materi Invertebrata; 3) Mengetahui interaksi antara metode pembelajaran mind mapping dan motivasi belajar terhadap keterampilan berpikir kreatif peserta didik pada materi Invertebrata. 


\section{METODE}

Rancangan penelitian yang digunakan dalam penelitian ini adalah rancangan penelitian eksperimen semu atau quasi eksperiment. Desain yang digunakan adalah Pre Test-Post Test Nonequivalent Control Group Design. Populasi dalam penelitian ini adalah semua peserta didik Kelas X MIPA di SMA Negeri 6 Metro Tahun Pelajaran 2019/2020 yang terdiri dari tiga kelas. Sampel dalam penelitian ini sebanyak dua kelas. Setiap pembelajaran diwakili oleh satu kelas. Kelas X MIPA 1 sebagai kelas eksperimen metode mind mapping, dan Kelas $\mathrm{X}$ MIPA 2 sebagai kelas kontrol metode konvensional. Jumlah peserta didik Kelas X MIPA 1 adalah 28, Kelas X MIPA 2 berjumlah 26 peserta didik. Pemilihan kelas tersebut dilakukan secara acak (random sampling), dengan pertimbangan kelas X MIPA 1 dan X MIPA 2 memiliki kemampuan akademik yang setara dan diperkuat melalui analisis varian (anava) dengan bantuan software SPSS 22.0 for Windows. Data yang dianalisis adalah nilai mata pelajaran IPA saat Ujian Nasional SMP pada peserta didik Kelas X MIPA 1 dan X MIPA 2.

Cara untuk mengetahui keterampilan berfikir kreatif peserta didik adalah dengan menggunakan rubrik mind mapping (peta pikiran) saat pre test dan post test. Lembar Kerja Peserta Didik (LKPD) yang digunakan dalam penelitian ini adalah LKPD yang sesuai dengan metode pembelajaran mind mapping. Angket digunakan untuk memperoleh informasi motivasi belajar peserta didik, yaitu angket motivasi Attention, Relevance, Confidence, Satisfaction
$(A C R S)$ yang diadaptasi oleh peneliti. Validitas kualitatif dalam hal ini adalah validitas bahasa dalam instrumen yang bertujuan untuk menentukan kebenaran dan kejelasan bahasa yang dipakai dalam menyusun rubrik mind mapping. Rubrik digunakan untuk mengukur keterampilan berpikir kreatif peserta didik pada mind mapping saat pre test dan post test.

\section{HASIL}

\section{Data Motivasi}

Gambar 1 menunjukkan bahwa tingkat motivasi belajar peserta didik berada pada rentang 60 hingga 79 artinya masuk dalam kategori motivasi belajar cukup (kategori C) dan motivasi belajar baik (kategori B).

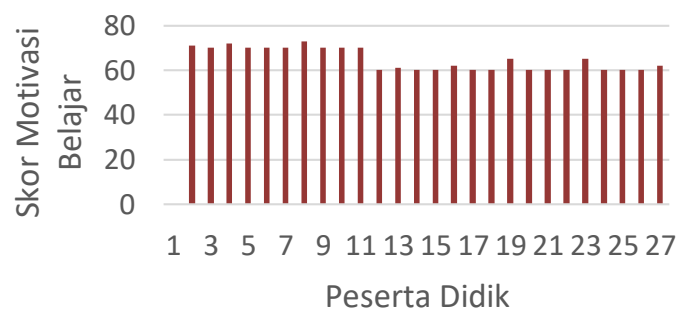

Gambar 1. Diagram Batang Motivasi Belajar Peserta Didik Kelas Eksperimen

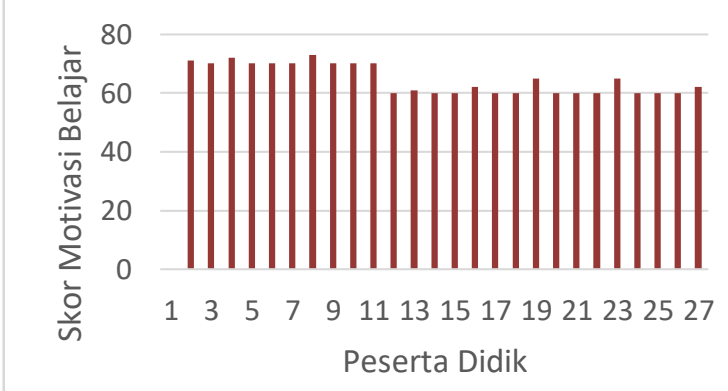

Gambar 2. Diagram Batang Motivasi Belajar Peserta Didik Kelas Kontrol

Gambar $\quad 2 \quad$ tersebut menunjukkan bahwa tingkat motivasi belajar peserta didik kelas kontrol berada pada rentang 60 hingga 73 
artinya masuk dalam kategori motivasi belajar cukup (kategori C) dan motivasi belajar baik (kategori B).

$$
\begin{array}{r}
100 \\
80 \\
60 \\
40 \\
20 \\
0
\end{array}
$$

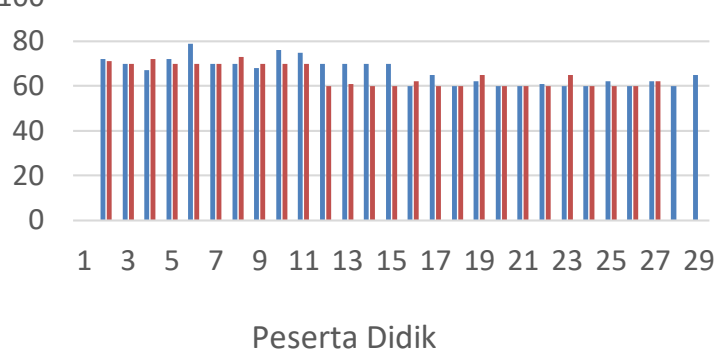

$\begin{array}{ccr}\text { Gambar } & \begin{array}{c}\text { Ekperimen } \\ \text { 3. Kontrol Diagram }\end{array} & \text { Batang } \\ \text { Perbandingan } & \text { Motivasi } \\ \text { Belajar Peserta Didik } & \text { Kelas } \\ \text { Eksperimen dan } & \text { Kelas } \\ \text { Kontrol } & & \end{array}$

Data Gambar 1, 2, 3. menunjukkan bahwa rentang nilai kedua kelas eksperimen dan kelas kontrol tidak terpaut jauh. Sehingga dapat disimpulkan bahwa nilai motivasi kelas ekperimen dan kelas kontrol setara dan keduanya samasama memiliki dua kategori tingkat motivasi yaitu kategori motivasi belajar cukup (kategori C) dan motivasi belajar baik (kategori B).

\section{Data Keterampilan Berpikir Kreatif}

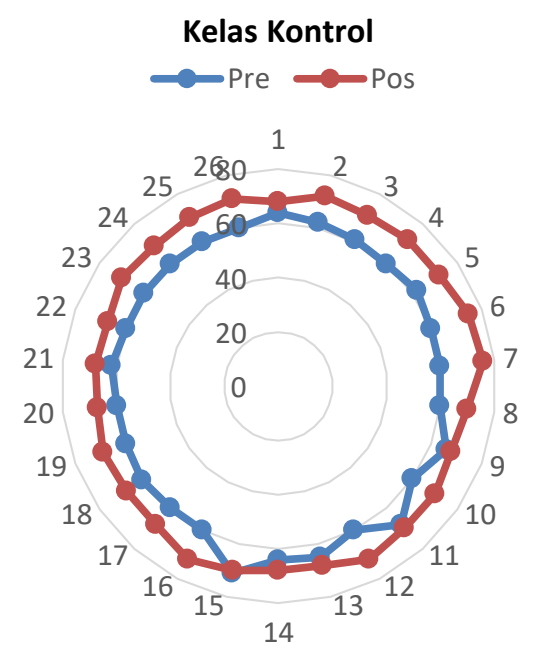

Gambar 4. Diagram Nilai Pre Test dan Data Post Test Keterampilan Berpikir Kreatif Peserta Didik di Kelas Eksperimen.
Data Gmbar 4. tersebut merupakan data pre test dan data post test keterampilan berpikir kreatif peserta didik dikelas eksperimen. Gambar 4 menunjukkan perbedaan nilai saat pre test dan data post test. Rentang nilai pre test keterampilan berpikir kritis peserta didik berada pada nilai 60-72 sedangkan rentang nilai pest test berada dbada nilai 75-89.

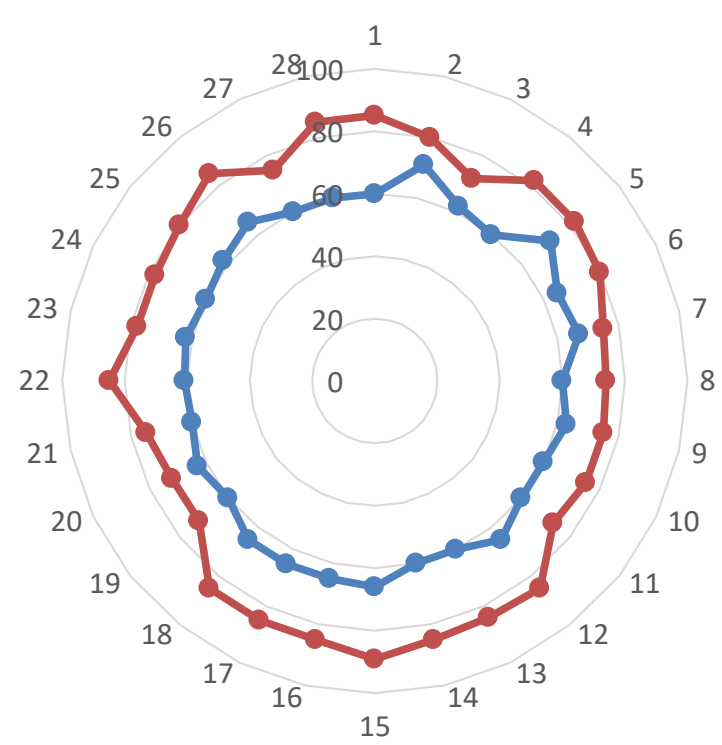

Data Gambar 5. tersebut merupakan data pre test dan data post test keterampilan berpikir kreatif peserta didik di kelas kontrol. Gambar menunjukkan perbedaan nilai saat pre test dan data post test keterampilan berpikir kreatif peserta didik dikelas kontrol. Gambar menunjukkan perbedaan nilai saat pre test dan data post test. rentang nilai pre test keterampilan berpikir kritis peserta didik kelas kontrol berada pada nilai 60-71 sedangkan rentang nilai post test. berada pada nilai 68-76. 
Tabel 1. Hasil Analisis Data dan Pengujian Hipotesis Penelitian

\begin{tabular}{|c|c|c|c|c|c|}
\hline Source & $\begin{array}{l}\text { Type III } \\
\text { Sum of } \\
\text { Squares }\end{array}$ & df & $\begin{array}{r}\text { Mean } \\
\text { Square }\end{array}$ & $\mathbf{F}$ & Sig. \\
\hline $\begin{array}{l}\text { Correcte } \\
\text { d Model }\end{array}$ & $1367,830^{\mathrm{a}}$ & 4 & 341,958 & $\begin{array}{r}20,88 \\
6\end{array}$ & $\begin{array}{r}, 00 \\
0\end{array}$ \\
\hline Intercept & 516,778 & 1 & 516,778 & $\begin{array}{r}31,56 \\
3 \\
\end{array}$ & $\begin{array}{r}, 00 \\
0\end{array}$ \\
\hline Xkreatif & 20,718 & 1 & 20,718 & 1,265 & $\begin{array}{r}, 26 \\
6\end{array}$ \\
\hline Kelas & 1108,776 & 1 & $\begin{array}{r}1108,77 \\
6\end{array}$ & $\begin{array}{r}67,72 \\
1\end{array}$ & $\begin{array}{r}, 00 \\
0\end{array}$ \\
\hline Motivasi & 1,067 & 1 & 1,067 & ,065 & $\begin{array}{r}, 80 \\
0\end{array}$ \\
\hline $\begin{array}{l}\text { Kelas * } \\
\text { Motivasi }\end{array}$ & 52,676 & 1 & 52,676 & 3,217 & $\begin{array}{r}, 07 \\
9 \\
\end{array}$ \\
\hline Error & 802,262 & $\begin{array}{l}4 \\
9 \\
\end{array}$ & 16,373 & & \\
\hline Total & $\begin{array}{r}306971,00 \\
0 \\
\end{array}$ & $\begin{array}{l}5 \\
4 \\
\end{array}$ & & & \\
\hline $\begin{array}{l}\text { Correcte } \\
\text { d Total }\end{array}$ & 2170,093 & $\begin{array}{l}5 \\
3 \\
\end{array}$ & & & \\
\hline
\end{tabular}

Berdasarkan ringkasan hasil uji anakova pada Tabel 1. Di atas, F hitung perlakuan perbedaan pembelajaran mind mapping adalah sebesar 67,721 dengan signifikansi 0,000 . Nilai signifikansi tersebut kurang dari 0,05. Dengan demikian, $\mathrm{H} 0$ yang berbunyi tidak ada perbedaan keterampilan berpikir kreatif antara peserta didik yang menerima pembelajaran mind mapping berbeda ditolak. Maka, hipotesis penelitian yang berbunyi ada perbedaan keterampilan berpikir kreatif antara peserta didik yang menerima pembelajaran mind mapp berbeda diterima. Artinya, ada pengaruh penerapan pembelajaran terhadap pencapain keterampilan berpikir kreatif peserta didik.

F hitung pada perlakuan perbedaan motivasi dan pembelajaran mind mapping adalah sebesar 0,065 dengan signifikansi 0,800 . Nilai signifikansi tersebut lebih dari 0,05 . Dengan demikian, H0 yang berbunyi tidak ada perbedaan keterampilan berpikir kreatif antara peserta didik dari tingkat motivasi yang berbeda diterima. Maka, hipotesis penelitian yang berbunyi ada perbedaan keterampilan berpikir kreatif antara siswa dari tingkat motivasi yang berbeda ditolak. Artinya, tidak ada pengaruh motivasi terhadap pencapaian keterampilan berpikir keatif peserta didik.

F hitung terkait interaksi penerapan pembelajaran mind mapping dan motivasi adalah sebesar 3,217 dengan signifikansi 0,079 . Nilai signifikansi tersebut lebih dari 0,05 . Dengan demikian, H0 yang berbunyi tidak ada perbedaan keterampilan berpikir keatif terkait interaksi antara pembelajaran mind mapping dan motivasi diterima. Maka, hipotesis penelitian yang berbunyi ada perbedaan keterampilan berpikir kreatif terkait interaksi antara pembelajaran mind mapping dan motivasi ditolak. Artinya, tidak ada interaksi pembelajaran dan motivasi terhadap pencapain keterampilan berpikir kreatif peserta didik.

\section{PEMBAHASAN}

\section{Pengaruh Pembelajaran Mind Mapping terhadap Keterampilan Berpikir Kreatif Peserta Didik}

Hasil pengolahan data penelitian menunjukkan bahwa terdapat pengaruh yang signifikan terkait metode pembelajaran mind mapping terhadap keterampilan berpikir kreatif peserta didik pada materi Invertebrata. Temuan tersebut dapat terjadi karena pembelajaran mind mapping mampu merangsang peserta didik untuk memaksimalkan kinerja otaknya menjadi lebih kreatif dan sangat melekat pada peserta didik. Hal tersebut sejalan dengan apa yang dipaparkan Akbar (2017:76) yang menyatakan bahwa menggunakan mind mapping dalam pembelajaran 
akan mampu membuat peserta didik mengingat materi lebih lama. Meskipun kenyataan bahwa pembelajaran diskusi juga mampu merangsang dan memotivasi peserta didik untuk lebih aktif dan kreatif, namun hasil penelitian menunjukkan bahwa mind mapping mampu membawa peserta didik lebih unggul dalam mendorong peserta didik memiliki keterampilan berpikir kreatif.

Prosedur pembuatan mind mapping yang dituangkan dalam Lembar Kerja peserta Didik (LKPD) yang telah disusun dan divalidasi oleh para ahli terkait kebahasaan, kegrafisan serta konten (isi) dengan kriteria tinggi, mampu mengarahkan peserta didik menggunakan banyak jalan atau cara agar hasil mind mapping yang dibuat sesuai dengan kriteria ideal sebuah mind mapping. Melalui pembuatan mind mapping, maka peserta didik akan mampu menghasilkan banyak kompensasi alternatif dengan proses berpikir konvergensi, yaitu peserta didik diarahkan untuk menemukan ide-ide baru dan lebih beragam dan tentunya lebih kreatif dan inovatif dalam menentukan bentuk konten jumlah cabang mind maping yang akan dibuat. Peserta didik yang diajarkan dengan menggunakan pembelajaran mind mapping telah membuktikan hasil belajar yang lebih baik dalam mengakses keterampilan kreativitas peserta didik dibandingkan dengan pembelajaran konvensional. Temuan tersebut sejalan dengan penelitian sebelumnya oleh Akbar (2017) bahwa secara konklusif, temuan penelitian cenderung menunjukkan bahwa pembelajaran mind mapping, dapat dipilih dalam pembelajaran secara efisien karena teknik belajar dapat meningkatkan pengetahuan siswa secara langsung. dapat $\begin{array}{rr}\text { Pembelajaran } & \text { mind mapping } \\ \text { meningkat } & \text { keterampilan }\end{array}$ kreativitas peserta didik dan juga dapat digunakan sebagai alat evaluasi secara efektif dalam menilai keterampilan kreativitas peserta didik. Pembelajaran dengan menerapkan mind mapping akan membawa peserta didik melalui proses belajar dengan kesempatan luas untuk mengembangkan potensi pribadi lebih kreatif dan imajinatif mampu mengGambarkan permasalahan melalui cabang-cabang pikiran dalam mind mapping yang membawa peserta didik mudah dalam memahami sebuah materi. Dalam kajian teoritis dapat dikatakan bahwa penerapan pembelajaran mind mapping lebih baik untuk keterampilan berpikir kreatif peserta didik dalam proses pembelajaran bila dibandingkan dengan pembelajaran konvensional.

\section{Pengaruh Motivasi Belajar terhadap Keterampilan Berpikir Kreatif Peserta Didik}

Hasil penelitian menunjukkan bahwa terdapat pengaruh yang tidak signifikan terkait motivasi belajar peserta didik terhadap keterampilan berpikir kreatif peserta didik pada materi Invertebrata. Data menunjukkan bahwa peserta didik yang memiliki tingkat motivasi yang baik (kategori B) tidak berbeda secara signifikan dengan peserta didik yang memiliki motivasi belajar cukup (kategori C) pada kedua kelas yang dijadikan sampel penelitian. Artinya, tidak ada pengaruh motivasi belajar terhadap pencapaian keterampilan berpikir kreatif peserta didik. Hasil analisis angket yang diisi peserta didik menunjukkan bahwa dari lima kategori motivasi berdasarkan Arikunto (2009:245) bahwa terdapat kualitas motivasi peserta didik yang baik sekali dengan rentang (80-100) kategori A, kategori baik dengan 
rentang (66-79) kategori B, kategori cukup sekali dengan rentang (56-65) kategori C, kategori kurang sekali dengan rentang (40-55) kategori D, dan kategori gagal dengan rentang (30-39) kategori E. Hanya ditemukan dua kategori motivasi belajar pada peserta didik yaitu kategori motivasi belajar baik dengan kategori B dan juga motivasi belajar cukup dengan kategori C. Tidak semua peserta didik yang memiliki motivasi belajar baik memiliki keterampilan berpikir kreatif yang baik, sebab hasil penelitian menunjukkan bahwa tidak ada perbedaan yang signifikan antar peserta didik yang memiliki motivasi belajar yang baik dengan peserta didik yang masuk kategori motivasi belajar cukup.

\section{Interaksi antar Metode Pembelajaran Mind Mapping dan Motivasi Belajar terhadap Peserta Didik}

Hasil analisis data penelitian menunjukkan bahwa tidak terdapat interaksi antara metode pembelajaran mind mapping dan motivasi belajar yang berbeda pada peserta didik terhadap kemampuan berpikir kreatif peserta didik pada materi Invertebrata. Hasil penelitian menunjukkan fakta bahwa terdapat pengaruh yang muncul pada peningkatan keterampilan berpikir kreatif peserta didik melalui pembelajaran mind mapping dibandingkan dengan pembelajaran konvensional. Berbeda dengan hasil temuan pertama tersebut, data kedua menunjukkan bahwa tidak ada perbedaan pengaruh yang signifikan antara tingkat motivasi belajar peserta didik yang berbeda dengan peningkatan keterampilan berpikir kreatif peserta didik. Hasil penelitian yang diperoleh, bahwa tidak semua peserta didik yang memiliki motivasi belajar baik memiliki keterampilan berpikir kritis yang baik, karena hasil menunjukkan bahwa tidak ada perbedaan yang signifikan antar peserta didik yang memiliki motivasi yang baik dengan peserta didik yang masuk kategori motivasi belajar cukup.

\section{KESIMPULAN}

Berdasarkan analisis data hasil penelitian, maka dapat disusun kesimpulan: 1) Terdapat pengaruh yang signifikan terkait metode pembelajaran mind mapping terhadap keterampilan berpikir kreatif peserta didik pada materi Invertebrata; 2) Tidak terdapat pengaruh yang signifikan terkait motivasi belajar peserta didik terhadap keterampilan berpikir kreatif peserta didik pada materi Invertebrata; 3) Tidak terdapat interaksi antara metode pembelajaran mind mapping dan motivasi belajar yang berbeda terhadap kemampuan berpikir kreatif peserta didik pada materi Invertebrata.

\section{SARAN}

Berdasarkan hasil penelitian, maka untuk melatih ketrampilan berpikir kreatif, peserta didik tidak harus mesti tergantung motivasi belajarnya, bahkan motivasi tinggi sekalipun, tidak mesti dapat melatih ketrampilan berpikir kreatif. Metode pembelajaran mind mapping dapat disarankan untuk melatih ketrampilan berpikir kreatif.

\section{DAFTAR PUSTAKA}

Akbar, Raihama S. dan Hanan A. Taqi. 2017. Dose Mind Mapping Enhance Learning?. International Journal of English Language Teaching (Published by European Centre for Research Training and 
Development UK (Vol.5),

No.8, pp.65-77, Tahun 2017.

Arikunto, Suharsimi. 2009. Dasar-

Dasar Evaluasi Pendidikan

Edisi 2. Jakarta: Bumi Aksara.

Buzan, Tony. 2007. The Ultimate Book of Mind Maps: Buku Pintar Mind Map, Alih Bahasa: Susi Purwoko. Jakarta: Gramedia Pustaka Utama.

Sani, Ridwan Abdulah. 2014. Pembelajaran Saintifik untuk Implementasi Kurikulum 2013. Jakarta: PT Bumi Aksara.

Sawyer, R Keith. 2003. Creativity and Development. Oxford University Press. 